\title{
Fertilization in Ephedra altissima.
}

\author{
BY
}

\author{
EMILY M. BERRIDGE, B.SC., F.L.S.
}

\section{With Plate XXXVI.}

$\mathrm{IT}^{\mathrm{T}}$ is somewhat remarkable that, although the development of the pro1 thallium and archegonium in three species of Ephedra, E. helvetica, $E$. trifurca and $E$. distachya, has been very fully described, and the embryogeny in the first two carefully investigated, our knowledge of the important intermediate stage, that of fertilization, is still very imperfect. In the two cases of fertilization observed by M. Jaccard ${ }^{1}$ and Dr. Land ${ }^{2}$ the fusion of gametes is so advanced, that the individual nuclei are almost indistinguishable; moreover, in the figure given by the latter, the smallest nucleus, interpreted as the ventral canal nucleus, is evidently the second male, while that which more nearly approaches the egg in size is certainly the ventral canal nucleus.

It therefore seemed desirable to give a short account of some preparations obtained from ovules of E. altissima, illustrating the period of development from the germination of the pollen-grain and the separation of the ventral canal nucleus to the formation of the fusion nucleus.

The ovules were gathered, by kind permission of Lady Hanbury, in the garden of La Mortola, near Ventimiglia; most of them were fixed in acetic alcohol and stained with Heidenhain's iron haematoxylin. The material was collected on March 9, II, and I2, but as it was obtained from five different plants in varying stages of development, a close series was secured. By March I 3 all the fertilized ovules contained embryos.

The organization of the ovule in E. altissima before division of the central nucleus is almost identical with that of E. trifurca, as described by Dr. Land. The nucleus, which is closely applied to the apex of the archegonium, is large and contains a considerable amount of chromatin material collected in the middle, with a clear space surrounding it; the nucleolus also is large and prominent.

1 P. Jaccard: Recherches embryologiques sur l'Ephedra helvetica. Bulletin de la Société Vaudoise, $\mathrm{xxx}, \mathrm{I} 894$.

${ }^{2}$ W. J. G. Land : Fertilization and Embryogeny in Ephedra trifurca. Bot. Gaz., xliv, 272-290, 1907 .

[Annals of Botany, Vol. XXIII. No. XCI. July, 1909.] 
While in process of division, however, to form the egg and ventral canal nuclei, it is very inconspicuous owing to the diffuseness of the spindle and slenderness of the chromosomes, which number about twelve. The spindle is parallel to the long axis of the archegonium, and is limited at the sides by a series of vacuoles. The egg nucleus is usually somewhat larger than the ventral canal nucleus, but otherwise, when first formed, they resemble one another very closely. The former retreats into the egg-cell, but the latter remains close to the neck, and, like the synergidæ of the Angiosperms, is either pushed aside or broken up by the entry of the pollen-tube; in cases where no tube reaches the egg-cell it sometimes outlives the egg nucleus itself.

The earlier stages in the germination of the pollen-tubes could be followed within the pollen chamber, for the grains in the majority of cases germinate on the surface of a drop of liquid, the fixed remains of which form a structureless film across the mouth of the chamber. The pollengrain shown in Fig. 2 occurred in some material of $E$. distachya collected by Miss Sanday in Brittany; it shows the intine escaping from the exine, and indicates that the body cell has already divided, while still within the grain, into two equal gametes, as described by Dr. Land for E. trifurca. Fig. $3 a$ shows a slightly later stage in the development of the pollentube in E. altissima, while in Fig. $3 b$ the tube has elongated considerably; in this case the stalk-cell could not be traced. All these three figures show the two gametes enclosed in a well-marked, but not very dense sheath of cytoplasm, and in this they appear to travel through the neck down to the egg-cell, for in Fig. 4, where the tip of the tube is in actual contact with the wall of the egg-cell, the nuclei still occupy the same relative positions, and some trace of the sheath is still to be seen. In this last case this pollen-tube has been forestalled by another, which has evidently caused great disturbance of the cytoplasm of the egg; the ventral-canal nucleus has been broken up and swept aside by the inrush of the contents of the pollen-tube.

Figures 2, $3 \alpha$, and 4 are all drawn to the same scale and illustrate the increase in size of the two gametes as they pass down the tube. Their average diameter in Fig. $3 \alpha$ is $10 \mu$, in Fig. 4 it is $14 \mu$, while of those represented in Fig. 5 within the archegonium and drawn on a smaller scale, the first sperm $\left(m_{1}\right)$ measures about I9 $\mu$, and the second male gamete $\left(m_{2}\right)$, which is probably beginning to enlarge and degenerate, about $2 \mathrm{I} \mu$ in diameter. The statement was made in a previous paper ${ }^{1}$ that the male gametes are unequal in $E$. distachya; in several pollen-tubes they appear distinctly unequal; the second one, however, is usually very irregular in shape, and shows signs of breaking up into two or more. That fragmentation

${ }^{1}$ E. M. Berridge and E. Sanday. Oogenesis and Embryogeny in Ephedra distachya. New Phytologist, vi, $5,6,7,1907$. 
does occur seems probable from the fact that, more than once, five or six small nuclei are found in the egg-cell near the mouth of the pollen-tube; also it is likely that the small nucleus associated with a male gamete, as represented in Fig. I3 of that paper, is really one of these secondary nuclei.

In several archegonia fusion of the gametes was taking place at the time of the fixing of the ovule. In the preparation represented in Fig. 5 the two nuclei although in contact are quite distinct. The male nucleus is closely granular in structure, and therefore appears darkly stained, the egg contains much larger fragments of chromatin material and shows a clear area just within the nuclear wall. No layer of dense cytoplasm is to be observed round the fusing nuclei, but they are surrounded by delicate radiations of the general cytoplasm of the egg-cell, which extend up to, and enclose the second sperm, which is more vacuolate and slightly larger than the first, probably because it has already begun to degenerate. These cytoplasmic radiations become more marked as fusion progresses, they also surround the daughter nuclei of this nucleus when they are first formed. The ventral canal nucleus still persists, though it also shows signs of degeneration. In another archegonium fusion of the gametes is almost complete, and here again no sheath of denser cytoplasm can be discerned, only a wide band of delicate radiating strands of cytoplasm. In this case the second male gamete has remained close to the neck and resembles the first gamete of Fig. 5 in its size and closely granular structure. The ventral canal nucleus still persists as an irregular diffuse nucleus lying against the apical wall of the archegonium.

Nothing like the post-fertilization activity of the jacket cells in $E$. distachya is to be observed in E. altissima; the nuclei divide once by mitotic division as a rule, just after fertilization has occurred in the eggcell, and then degenerate and die.

A comparison of $E$. altissima with $E$. distachya emphasizes the abnormality of the latter; it is hoped that a fresh gathering of ovules this season may determine whether this abnormal development in the latter is habitual or only due to adverse circumstances.

\section{SUMMARY.}

The nucleus of the central cell of the archegonium divides and gives rise to a ventral canal nucleus very similar to the egg nucleus, but slightly smaller. This persists as a rule without degenerating till after fertilization has occurred.

The body-cell of the pollen-grain divides into two equal gametes before the male gametophyte leaves the exine; these travel down the tube enclosed in a cytoplasmic sheath. 
Both gametes enter the egg-cell, but no cytoplasm was observed to pass with the first sperm to the egg nucleus. The first male gamete is very small, round, and densely granular; it applies itself to the pointed end of the egg nucleus, which is directed to the neck of the archegonium. A zone of radiating strands of cytoplasm appears round the fusion nucleus.

The nuclei of the jacket cells divide once, and then die after fertilization is accomplished.

\section{EXPLANATION OF FIGURES IN PLATE XXXVI.}

Illustrating Miss Berridge's paper on Ephedra altissima.

Abbreviations.-ar. egg-cell of archegonium; $n$. neck-cell; p.t. pollen-tube; $m_{1}$. first male gamete; $m_{2}$. second male gamete; $t$. tube nucleus; s. stalk-cell; e. egg nucleus; $v . c$. ventral-canal nucleus.

Fig. I. The nucleus of the central cell undergoing division. $\times 375$.

Fig. 2. Male gametophyte of $E$. distachya escaping from the exine of the pollen-grain. $\quad \times 1000$

Fig. $3 a$. Commencement of poilen-tube in E. altissima. $\times 1000$.

Fig. $3 b$. Older pollen-tube with male gametes and tube nucleus. The full length of the pollentube is not represented. $\times 5^{80}$.

Fig. 4. Tip of the pollen-tube fused with the wall $(w)$ of the egg-cell. $\times 1000$.

Fig. 5. Fusion of first male gamete and egg nucleus. $\times 320$. 

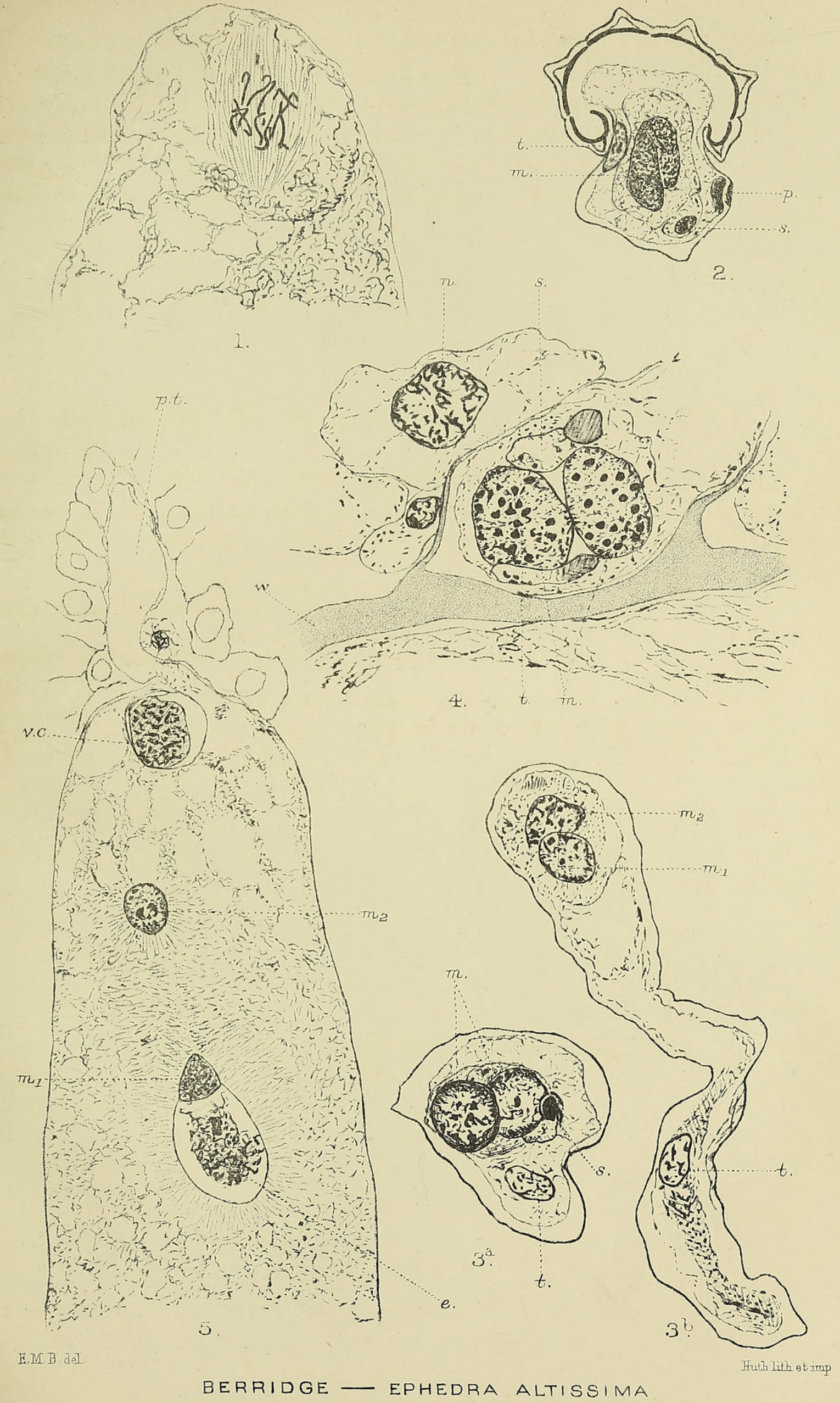


\section{$2 \mathrm{BHL}$ Biodiversity Heritage Library}

Berridge, Emily Mary. 1909. "Fertilization in Ephedra altissima." Annals of botany 23, 509-512. https://doi.org/10.1093/oxfordjournals.aob.a089234.

View This Item Online: https://www.biodiversitylibrary.org/item/236540

DOI: https://doi.org/10.1093/oxfordjournals.aob.a089234

Permalink: https://www.biodiversitylibrary.org/partpdf/318969

\section{Holding Institution}

Smithsonian Libraries

\section{Sponsored by}

Biodiversity Heritage Library

\section{Copyright \& Reuse}

Copyright Status: Not in copyright. The BHL knows of no copyright restrictions on this item.

This document was created from content at the Biodiversity Heritage Library, the world's largest open access digital library for biodiversity literature and archives. Visit BHL at https://www.biodiversitylibrary.org. 